\title{
Packages influencing BRS Vitória raisins quality maintenance
}

Vanessa Ferreira Caldeira vanessa fc95@hotmail.com vanessa fc95@hotmail.com Universidade
Bahia, Brasil.

\section{Sabrina Moura Guimarães} sabrinaguimaraaes@hotmail.com Universidade do Estado da Bahia, Juazeiro, Bahia, Brasil.

\section{Ana Cecília Poloni Rybka} ana.rybka@embrapa.br Empresa Brasileira de Pesquisa Agropecuária, Embrapa Semiárido Petrolina, Pernambuco, Brasil.

Aline Camarão Telles Biasoto aline.biasoto@embrapa.br Empresa Brasileira de Pesquisa Agropecuária, Embrapa Semiárido, Petrolina, Pernambuco, Brasil.

\section{Sergio Tonetto Freitas} sergio.freitas@embrapa.br Empresa Brasileira de Pesquisa Agropecuária, Embrapa Semiárido Petrolina, Pernambuco, Brasil.

\section{Rita de Cássia Mirela Resende} Nassur

ritarnassur@hotmail.com

Universidade do Estado da Bahia, Juazeiro, Bahia, Brasil.

\begin{abstract}
Grapes cultivation can generate different processed products, such as wines, juices and raisins. Dehydrated fruit is widely consumed due to its benefits, being rich in antioxidants and phenolic compounds. The 'BRS Vitória' grape variety was developed in Brazil, presenting a high potential for raisins production. However, there are still no studies on the use of packaging to maintain the quality of raisins obtained from the 'BRS Vitória' variety. The aim of the present study was to evaluate the effect of three packages on the quality maintenance of 'BRS Vitoria' raisins during its shelf life for a period of 120 days. Raisins were obtained by placing grapes in forced air oven at $60^{\circ} \mathrm{C}$ for about 72 hours and were packed in sealed metallized polyethylene (PL), transparent polypropylene (PP) bags and polystyrene (PE) pots with lids. Grape samples were evaluated at 0, 30, 60, 90 and 120 days of storage at $25^{\circ} \mathrm{C}$ for titratable acidity, $\mathrm{pH}$, color, soluble solids, firmness, antioxidant activity, total phenolics and anthocyanin. The results were submitted to variance analysis (ANOVA). In addition, a multivariate statistical analysis was performed. According to the results, it was observed that the packages did not provide significant changes in quality parameters evaluated in 'BRS Vitória' raisins, indicating the appropriate packaging as the one with the lowest cost, the transparent polypropylene. The antioxidant activity of the raisins was only affected by the storage time, remaining with levels of antioxidant activity until the end of storage. In addition, the storage time also influenced the raisins firmness and color. It was observed a significant interaction between storage time and packaging in the total phenolics content. According to the multivariate analysis, the storage time was the main influencing factor of the studied variables, regardless the used package.
\end{abstract}

KEYWORDS: Dehydrated fruits; storage; phenolic compounds; antioxidant activity. 


\section{INTRODUCTION}

Brazil is one of the world's largest fruit producers, being the main fruit crops produced bananas, apples, grapes, melons and mango (OECD-FAO, 2015). The region of the Submedium of the São Francisco Valley, located in the northeast of Brazil, is highlighted in the national and international grapes production scenario, with different productive capacity, with the possibility of more than one harvest per year (SANTOS et al., 2011), which is different from the other traditional regions of production, that present one harvest per year. From grapes cultivation is possible to obtain processed food products, such as wines, juices, jellies, and others, which can have contents of functional nutrients, mainly due to their content of antioxidants and phenolic compounds (LINS and SARTONI, 2014; VILAS BOAS et al. 2016, RIGOTTI et al., 2016; JAVED et al., 2018). In the last decades several studies have highlighted the positive effects of the consumption of foods rich in these components (BREKSA et al., 2010, ACHKAR et al., 2013, GUEDES, 2013, SANTOS and OLIVEIRA, 2013).

The fruit industrialization allows its transformation into products with high added value, such as the obtainment of dried fruits, which are products with increasing demand due to the the need of consumers for convenient foods, being the raisins inserted in this scenario (SOUZA et al., 2015).

Besides its consumption due to health benefits, the raisins can be used as an additional ingredient in other foods (CORNEJO; NOGUEIRA; WILBEG, 2003). The national production of raisins is low, mainly due to the small areas growing seedless grapes cultivars (FREITAS et al., 2013). Most of the raisins consumed in Brazil are therefore imported from countries such as Argentina, Chile, Iran and the United States of America. From 2012 to 2014, Brazil imported an average of 24,000 tons of raisins (MELLO, 2016).

The production of raisins requires little investment in equipment, especially in places with low relative humidity, and the product can be stored under ambient conditions (FELDBERG, 2008). The obtaining process of the product is the grape dehydration by removing the water from the interior to the external surface, which can be done by different methods, such as the sun or oven drying (CARRANZACONCHA et al., 2012; CONDE et al., 2018). Drying techniques can lead to physical and chemical changes, where the main objectives are to increase the food stability during storage and to minimize the costs with packaging and transportation (CORNEJO; NOGUEIRA; WILBEG, 2003).

In addition to the benefits that the raisins consumption can lead, it is important to enable the maintenance of compounds of nutritional interest during the storage of the processed product. Thus, it is necessary to take into consideration that the different types of packaging used during storage can influence the contents and preservation of its compounds of interest, extending the shelf life.

Food packaging can avoid light, heat, moisture and microorganisms deterioration in food. There are several types of packaging produced from different materials, which are used according to the product or food. The different types of materials and characteristics can maintain food in good conditions for 
exposed to different conditions that can influence the product quality, different packaging materials can determine the food conservation (UDOMKUN et al., 2016).

The 'BRS Vitória' is a grape cultivar recently developed and presents excellent production in the region of the São Francisco Valley. This cultivar features black (bluish-black) and high-fertility buds (up to 40 ton/ha/year), spherical and small berries (average $17 \times 19 \mathrm{~mm}$ ) and thick skin. It presents a cycle of 90 to 135 days and high resistance to mildew (MAIA et al., 2012). Currently, this new cultivar has aroused the interest of the growers and its production for the national and international market has increased considerably. Due to its quality characteristics, previous studies have identified the cultivar 'BRS Vitória' as a genotype with high potential for the production of raisins in the São Francisco Valley (FREITAS et al., 2013).

Thus, the aim of this study was to evaluate the effect of three packages, sealed metalized polyethylene, transparent polypropylene and polystyrene pots with lids in maintaining quality parameters of 'BRS Vitória' raisins during 120 days of storage.

\section{MATERIALS AND METHODS}

The 'BRS Vitória' seedless grapes, cultivated in Petrolina, Pernambuco, Brazil, were harvested at the maturation stage used for 'in natura' consumption and were degraned, washed, sanitized (100 ppm of active chlorine), weighed and placed in trays for drying at $60^{\circ} \mathrm{C} \pm 5{ }^{\circ} \mathrm{C}$, in oven (model TE-394/2 - Tecnal, Piracicaba, SP, Brazil), with forced air circulation. During this period (about 72 hours), the fruits were revolved on the trays on every 12 hours for the homogenization during drying, in that same period the grapes weight was evaluated until reaching constant weight (end of the drying).

The grapes were dried until achieving fruit water activity of 0.4. After drying, $30 \mathrm{~g}$ portions of raisins were packed in sealed metalized polyethylene (PE) packs, transparent polypropylene (PP) $(10 \times 15 \mathrm{~cm})$ and polystyrene (PS) pots with lids (volume $100 \mathrm{~mL}$ ). Each type of packaging was represented by three repetitions of each treatment and storage time. The raisins samples were evaluated at $0,30,60$, 90 and 120 days of storage at $25^{\circ} \mathrm{C}$, consisting of a $3 \times 5$ treatment ( 3 packages $\times 5$ storage times). Fruits before drying were evaluated for their initial quality of firmness, soluble solids, total acidity, $\mathrm{pH}$ and color.

The evaluations were carried out from day 0 to 120 days of storage and consisted of:

$-\mathrm{pH}$, realized by potentiometry according to AOAC (2012) in with the aid of a titrator with a potentiometer model Titrino plus 848 (Metrohm, São Paulo, SP, Brazil).

-Titratable acidity determined according to the methodology suggested by AOAC (2012) with results expressed as \% of tartaric acid.

-Color, evaluated with the aid of a CR-400 colorimeter (Konica Minolta, Japan), being the results expressed in the $\mathrm{L}, \mathrm{a}^{*}$ and $\mathrm{b}^{*}$ scales in the CIELab system. The Chroma values were calculated using the formulae: $\mathrm{C}=\sqrt{a^{2}=b^{2}}$. The hue angle was calculates using the formulae: Hue $=\operatorname{tg}^{-1} \frac{b *}{a *}$ 
- Soluble solids (SS), obtained using a refractometer model PAL-1 (ATAGO, Ribeirão Preto, SP, Brazil). For the analyzes of $\mathrm{pH}$, titratable acidity and soluble solids the samples $(5 \mathrm{~g})$ were homogenized with $50 \mathrm{~mL}$ of distilled water.

- Firmness, obtained by using a TA-XT Plus Texture Analyzer (Extralab, Brazil).

-Antioxidant activity, determined using the 2,2-diphenyl-1-picrylhydrazyl (DPPH) and according to Rufino et al. (2007). This methodology is based on the capture of DPPH (free radical) by antioxidants. For this, extracts were prepared using the different macerated raisin samples, the reagents used in this step were $50 \%$ methanol and $70 \%$ acetone and the contents were submitted to centrifugation. The DPPH solution was prepared on the day of analysis and was used to add to the extracts containing the samples and to determine the standard curve. The reading was performed at $515 \mathrm{~nm}$ in a spectrophotometer and and the results are expressed as percentage of free radical sequestration (\% SRL).

-Phenolic compounds, determined by spectroscopy in the visible region using the Folin-Ciocalteu method (SINGLETON; ORTHOFER; LAMUELA-RAVENTOS, 1999). The extract used for this method was the same for the evaluation of the antioxidant activity of the samples. All chemicals used for the analysis of phenolic compounds (Folin Ciocalteu, $70 \%$ ethanol, $20 \%$ sodium carbonate, gallic acid) were prepared at the time of analysis. The standard curve was drawn from different concentrations of gallic acid. Samples were read in a spectrophotometer at $735 \mathrm{~nm}$ and the results were expressed as gallic acid equivalents.

-Anthocyanin quantified according to the methodology of Giusti and WrolsItad (2001). The methodology for quantification of this pigment involves the use of buffer solutions (chloride buffer - $\mathrm{pH} 1$ and acetate buffer - $\mathrm{pH} \mathrm{4.5)} \mathrm{and} \mathrm{solvent}$ ethanol $50 \%$ acidified with $\mathrm{HCl}$. The sample is homogenized to the solvent and centrifuged for preparation of the extract. In a test tube $1.5 \mathrm{~mL}$ of the extract is homogenized with $2.5 \mathrm{~mL}$ of pH 1 buffer and in another tube $1.5 \mathrm{~mL}$ of the extract is homogenized with $2.5 \mathrm{~mL}$ of $\mathrm{pH} 4.5$ buffer. With the aid of the spectrophotometer, each tube was read at $510 \mathrm{~nm}$ and at $710 \mathrm{~nm}$.

The results were submitted to variance analysis (ANOVA). The quantitative factor storage time was submitted to regression analysis and the qualitative factor packaging was submitted to analysis by the Tukey test (5\%) with the aid of SISVAR ${ }^{\circledR}$ software. In addition, to optimize the visualization of results, a multivariate statistical analysis (Principal Components Analysis - PCA) was performed through the XLStat ${ }^{\circledR}$ software.

\section{RESULTS AND DISCUSSION}

The 'in natura' grapes, before drying process presented, on average, $26,3 \%$ of soluble solids, $0,52 \%$ of total acidity, and $\mathrm{pH}$ of 3,77 . For the color parameter, the observed luminosity $\left(L^{*}\right)$ was 22,48 , the coordinate $a^{*}-1,28$ and $b^{*} 0,99$. The For firmness it was observed 385,22 kgf. According to the Brazilian legislation (BRASIL, 2000), grape flesh characterization must present the minimum value for soluble solids of $14,0 \%$, total acidity of $0,41 \%$ of tartaric acid and $\mathrm{pH}$ of 2,9 . The values observed in the present study can be considered ideal when compared with those determined by the legislation. Machado, Souza and Novaes (2015), in a study with the Isabel grape variety to obtain raisins, characterizing the fruit before processing with $12.09 \%$ for soluble solids, $\mathbf{0 . 7 6 \%}$ of total acidity and observed a $\mathrm{pH}$ of 3,51 . 
The obtained raisins presented an average moisture of $77.9 \%$ and 0.4 of water activity.

The color parameter $L^{*}$ indicates the brightness of the product ranging from black (0) to white (100). According to the results obtained, it was observed the darkening of raisings with an increase of the storage time. No effect of the packaging was observed on the raisins darkening (Figure 1), with variations in the brightness parameter from 20,16 to 22.00 (Figure 1). The darkening occurred during storage of the grapes may have a consequence of an enzymatic action, in which enzymes such as peroxidase and polyphenoloxidase, for example, are involved in fruit and vegetables darkening and their processed products (FREITAS et al. The activity of these enzymes can be influenced and reduced as the temperature increases, however, in a study done by Freitas et al. (2008), enzymatic extracts containing peroxidase and polyphenoloxidase were evaluated and it was observed that thermal treatments used with temperatures between 60 and $85^{\circ} \mathrm{C}$ were not sufficient for the total inactivation of the enzymes. In the study, it is possible that the temperature used during the drying period $\left(60^{\circ} \mathrm{C}\right)$ did not influenced the activity of these enzymes and they remained in activity during storage, causing the darkening of the berries.

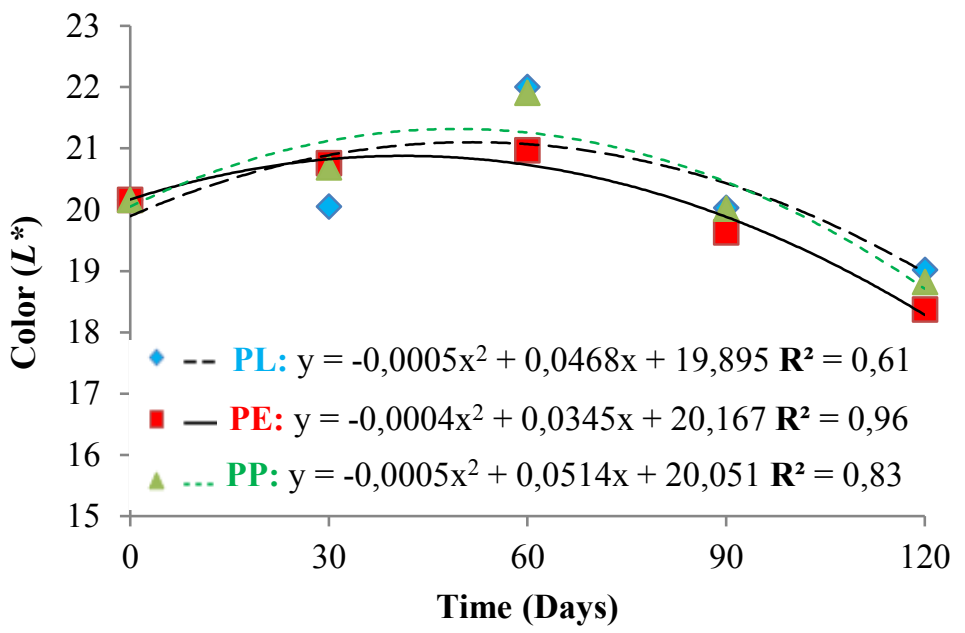

Figure 1. $L^{*}$ values of raisins stored for 120 days in different packages. PL: Laminated Polyethylene; PE: polystyrene with lid; PP: Transparent polypropylene.

In color analysis, the chromatic coordinate $a^{*}$, indicates the color ranging from red and green and in the present study it was observed that the variable was only affected by the storage time, regardless of the packaging used, presenting an average value of 2.41 being higher at the first period of evaluation (time $0-2.89$ ) and lower at 90 days of storage (1.99) (Figure 2). Positive data for $a^{*}$ is an indication of the overlap of red on green color, indicating that this color was more present in the grape samples and was slightly altered with time (Figure 2). Silva et al., 2015, in a study with Crimson raisins, reached, for the coordinate $a^{*}$, a value of approximately 3.8 in drying at $70^{\circ} \mathrm{C}$, indicating a predominance of red color.

This variable may be related to the presence of anthocyanin, which are pigments responsible for colors such as purple and different shades of red in fruits, 
stems and leaves (BRILHANTE et al., 2013). These elements are unstable; therefore, factors such as fruit processing, conditions and storage time can cause degradation. The temperature, the light and the presence of oxygen are variables that influence the deterioration process of the anthocyanin, resulting in color changes (SCHIOZER; BARATA, 2007).

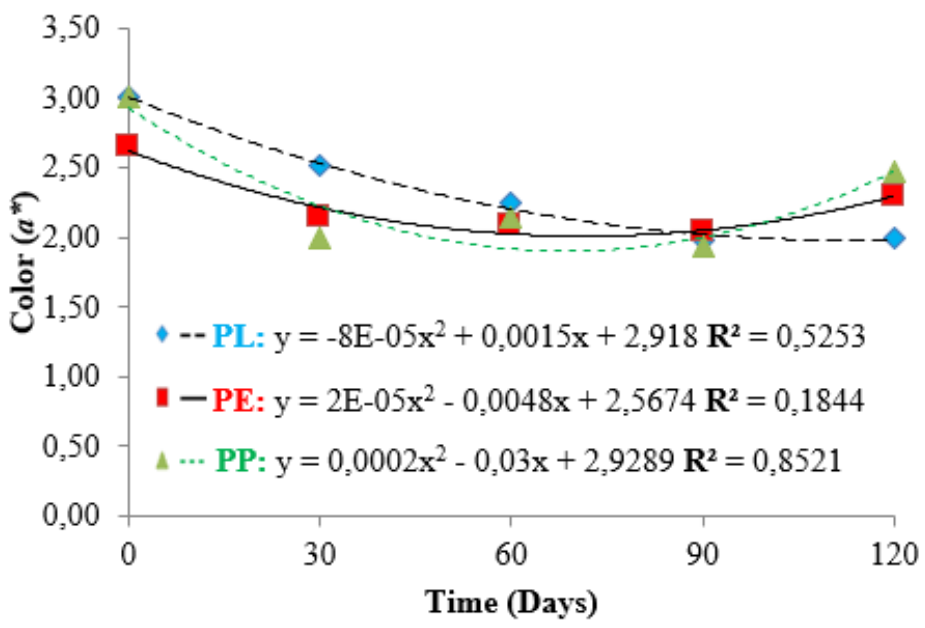

Figure 2. Coordinate $a^{*}$ (red/green) of raisins stored for 120 days in different packages. PL: Laminated Polyethylene; PE: polystyrene with lid; PP: Transparent polypropylene.

The parameter $b^{*}$ represents the change of tones between yellow and blue, where lower values indicate more bluish coloration of the fruits. No significant effect of packing and storage factors was observed. The mean values of $b^{*}$ observed were 1.42 for PL and PE and 1.27 for PP.

The chroma and Hue angle were calculated using the obtained $a^{*}$ and $b^{*}$ measurements. These variables are a more appropriate measurement of color. The hue angle of the samples varied in time (significant) and lower values were observed in samples at 0 days of storage (24.62) and higher values for 120 of storage (32.61), regardless the package. These values indicate color varying from yellow to orange, which indicate a saturation or intensity of the color. For the complete idea of the sample colors, it is necessary to take in consideration the $L^{*}$ values, which indicated the ranging from black (0) to white (100) - Figure 1 . The Chroma, commonly known as the color purity, were also calculated and lower values were observed for samples stored during 90 and 120 days (2.29 and 2.67, respectively).

Color is one of the factors that determine the presence of a food in the market (SANTOS et al., 2011). It is also associated with the degree of consumer acceptance. According to Rocha and Reed (2014), color is determined by the presence of pigments, some of these may play an important role in health. Flavonoids, for example, are part of a group of pigments and are subdivided into phenolics, anthocyanin and others; these are pigments present in red grapes, responsible for the skin and flesh color.

When raisins firmness was evaluated, significant differences during storage were observed, without the packing factor influencing the parameter. This 
parameter varied in time, on average, from $6.34 \mathrm{~N}$, on day 30 , to $1.71 \mathrm{~N}$, at 90 days (Figure 3 ). The chewing and firmness of fruits is a food quality parameter that the consumer considers at the time of purchase and should be observed, with different standards for different processed products. Freitas et al. (2013), evaluating sensorial parameters of raisins from different varieties, affirmed that the factors that influence most the consumption of this product were sweetness, succulence and softness and fruits that presented hardness and dryness characteristics were rejected. Rybka et al. (2015), in an experiment involving different drying conditions for 'Italia' grapes, observed values of $4.2 \mathrm{~N}$ for firmness of raisins after 48 hours at $56^{\circ} \mathrm{C}$.

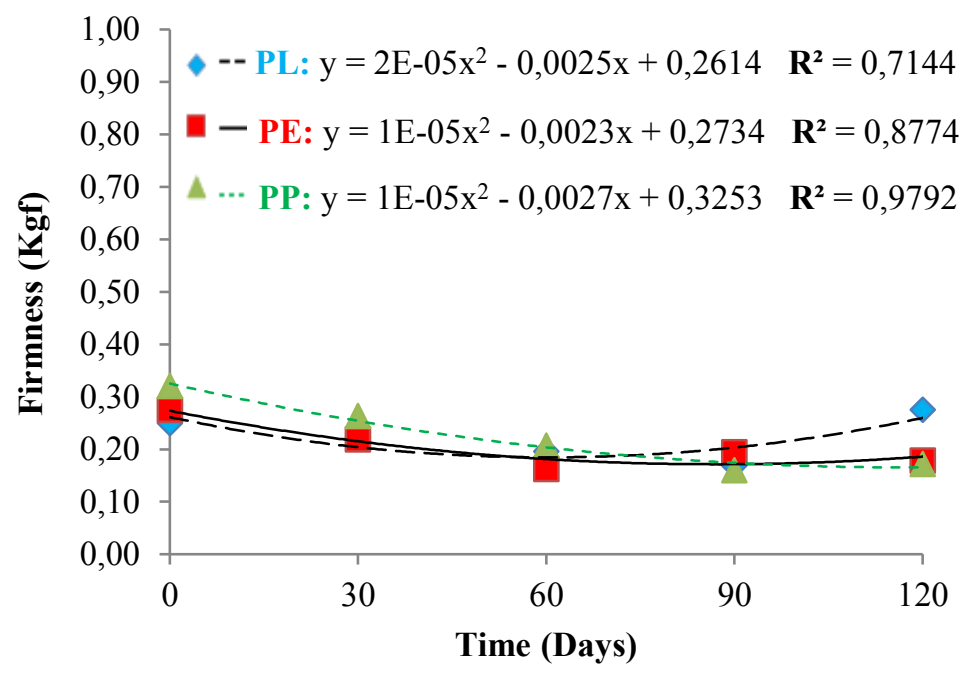

Figure 3. Firmness of raisins stored for 120 days in different packages. PL: Laminated Polyethylene; PE: polystyrene with lid; PP: Transparent polypropylene.

A significant effect of the packaging used and the storage time on the acidity of 'BRS Vitória' raisins was not observed. Mean and constant values of $1.8 \%$ were observed throughout the experiment (Figure 4). According to Koslosk et al., 2012, the acidity provides an assessment of the conservation status of a food product. In a study carried out by Carneiro et al. (2016), with blackberry jelly, packed in glass and polypropylene packages, it was not observed a significant influence on the acidity during storage using different packages.

Santos et al. (2011), in a research involving the chemical characterization of dehydrated grapes produced in the São Francisco Valley, observed acidity contents ranging from 2.4 and $10.7 \%$ of tartaric acid, highlighting the high acidity characteristic of the product. Costa et al. (2015), using the 'Itália' variety, from the same region, obtained, after dehydration at different temperatures, average acidity between 1.5 to $4.93 \%$.

This variable is associated with flavor, deterioration due to the microorganisms, reduction of the enzymatic darkening and decrease of reducing substances action. In fruits such as grapes there is a presence of natural acids, which are present during the fruit growth and development, such as malic acid, phenolic acids, predominating the tartaric acid (RIZZON; SGANZERLA, 2007). The 
sensory quality of grapes is perceived by the consumer based on their organoleptic properties, vision, taste, touch and smell and is closely linked to their harvesting point, to the cultural practices employed and to the environment to which it is inserted (MASCARENHAS et al. 2010).

The fruit taste is determined by the sum of factors such as sweetness, bitterness, salinity, astringency, volatile compounds and acidity (GUINÉ et al., 2010). These attributes were studied by Mascarenhas et al. (2010), which evaluated the acceptability of consumers for grapes of different varieties, 'Itália', 'Festival' ('Superior Seedless'), 'Benitaka' and 'Isabel', concluding that grapes with higher levels of soluble solids and low acidity achieved higher acceptance by users, highlighting the importance of this parameter in the commercialization of these fruits.

The $\mathrm{pH}$ values were affected by the used packaged, but by the interaction of the package with the storage time (Table 1). Constant behavior followed by an increase in fruit $\mathrm{pH}$ after 60 days of storage can be observed, despite the package. The highest mean was observed after 60 days of storage (4.1). Similar values were obtained with dehydration of 'Itália' grapes by Costa et al. (2015), which resulted in raisins with $\mathrm{pH}$ values between 3.5 and 4.5 .

Table 1. $\mathrm{pH}$ of raisins stored for 120 days in different packages.

\begin{tabular}{ccc}
\hline & $\mathrm{PH}$ & \\
\hline $\mathrm{PL}$ & $\mathrm{PE}$ & $\mathrm{PP}$ \\
\hline $37.30 \pm 0.68 \mathrm{Cb}$ & $41.83 \pm 0.17 \mathrm{Aa}$ & $40.27 \pm 0.96 \mathrm{Ba}$ \\
\hline
\end{tabular}

NOTE: PL: Laminated Polyethylene; PE: polystyrene with lid; PP: Transparent polypropylene. Averages followed by equal letters on the same line do not differ statistically by Tukey test $5 \%$.

It is understood that the small differences observed between the $\mathrm{pH}$ values of grapes stored in different packages, although significant, did not result from an interaction of the material used with the fruits, with a maximum variation of 0.07 in the contents.

Santos et al. (2011), states that the hydrogen ionic potential in food can considerably interfere in the growth of microorganisms by participating in the inhibition and reduction of microbial proliferation, resulting in safer products. According to Hoffmann (2001), pH values $\leq 4.5$, on average, avoid the multiplication of this type of organism. In addition, $\mathrm{pH}$ may be associated with enzyme activity, taste and stability.

Soluble solids comprise different soluble compounds in the food cell, responsible for flavor, such as carbohydrates and organic acids. This variable presents the amount of sugars and other soluble solids (GOUVEIA et al., 2014) of the sample. In the present study, the soluble solids content was not significantly altered by the packaging used, by the storage time and even by the interaction of the two factors, being possible to observe values from $71.3 \%$ to $82.0 \%$. According to the Ministry of Agriculture, 2000, the Identity and Quality Standards for the grape fruit indicate a minimum amount of $15 \mathrm{~g} / 100 \mathrm{~g}$ or \% of total soluble solids.

Silva et al. (2015), observed $17.3 \%$ of soluble solids in raisins of the 'Crimson' variety after the drying process. A study carried out by Ramos et al. (2008), 
evaluating the effect of packaging on the dried pineapple observed the decrease of the soluble solids, which was associated to the moisture gain during storage using polyethylene packages. Feldberg et al., (2008) observed $61.34 \%$ soluble solids contents in raisins produced in the northern region of the Minas Gerais state, Brazil, for the Crimson Seedless variety.

Figure 4 shows the average values for the antioxidant activity of grapes submitted to storage in different packages during the experimental period of 120 days. It is observed that during the experimental period this variable was influenced only by time, presenting, on average, $90.5 \%$ at day 0 and $85.9 \%$ after 120 days. The observed values of antioxidant activity observed during storage time indicate that even after decreasing, considerable levels of antioxidant content were observed. Vilas Boas et al. (2016), after evaluating the sequestering of free radicals in blends of grape juice observed mean values of $32.4 \%$ during 120 days of storage. The antioxidant activity in foods is related to the diversity of antioxidant compounds that are degraded or maintained according to the physiological state and abiotic and biotic factors during storage (ROTILI et al., 2013).

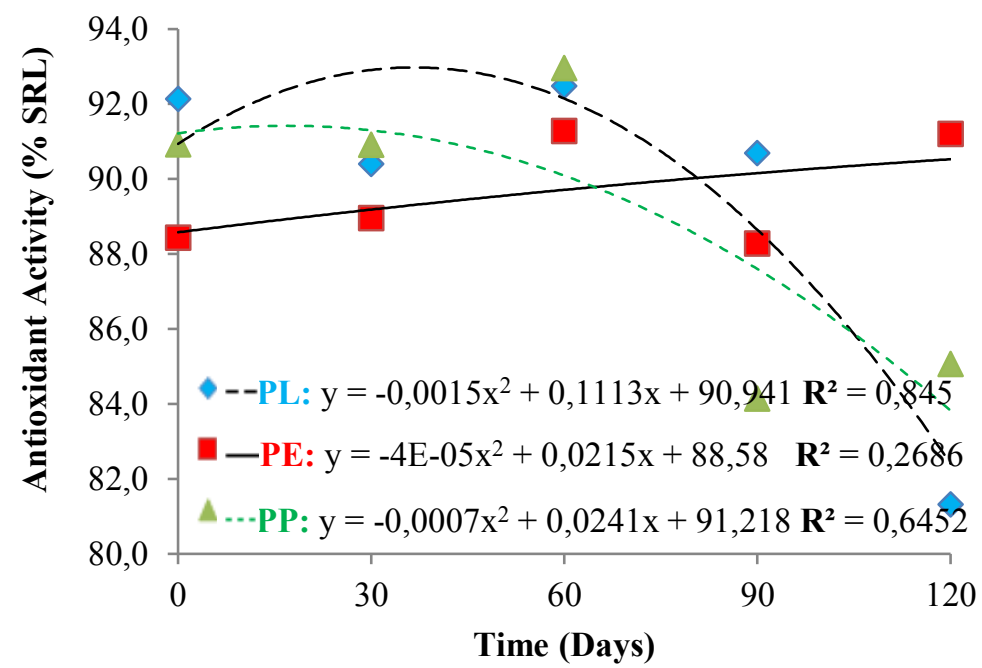

Figure 4. Antioxidant activity of raisins stored for 120 days in different packages. PL: Laminated Polyethylene; PE: polystyrene with lid; PP: Transparent polypropylene. Percentage of free radical sequestration (\% SRL).

Du et al. (2012) state that grapes are good sources of antioxidants, identifying \%SRL of $85.75 \%$ for 'Red Globe' grapes and $92.77 \%$ for 'Cabernet Sauvignon' grapes, not submitted to the drying process.

According to Zhang and Tsao (2016), these substances, present in some types of foods act in the prevention of chronic diseases and can contribute to minimize oxidative stress, which occurs in metabolic reactions, for example. When the grapes are inserted in the daily diet, essential nutrients such as fiber are obtained in values that contribute to health benefits, such as antioxidant, cardioprotective, anticancer, antiaging and antimicrobial effects (SÉRIO et al., 2014).

Regarding the phenolic content of 'BRS Vitoria' raisins, a significant interaction was observed between the studied factors (storage time and packaging) (Figure 5). 
It was observed higher maintenance of phenolic compounds contents in raisins stored in laminated polyethylene (PL) and lided polystyrene (PE) packages. PE packaging was effective in the maintenance of these compounds, since the highest values were found for this treatment, with an average content of $198,8\left(\mu \mathrm{m} . \mathrm{mg}^{-1}\right)$ EAG, with emphasis on time $60\left(254,1 \mu \mathrm{m} \cdot \mathrm{mg}^{-1} \mathrm{EAG}\right)$. With the time effect it was observed a decreasing tendency after 60 days $\left(190.9-140.8 \mathrm{mg}\right.$ EAG. $\left.\mathrm{L}^{-1}\right)$. In fruits stored in PL the contents of phenolic compounds showed the same tendency than in PE (Figure 5).

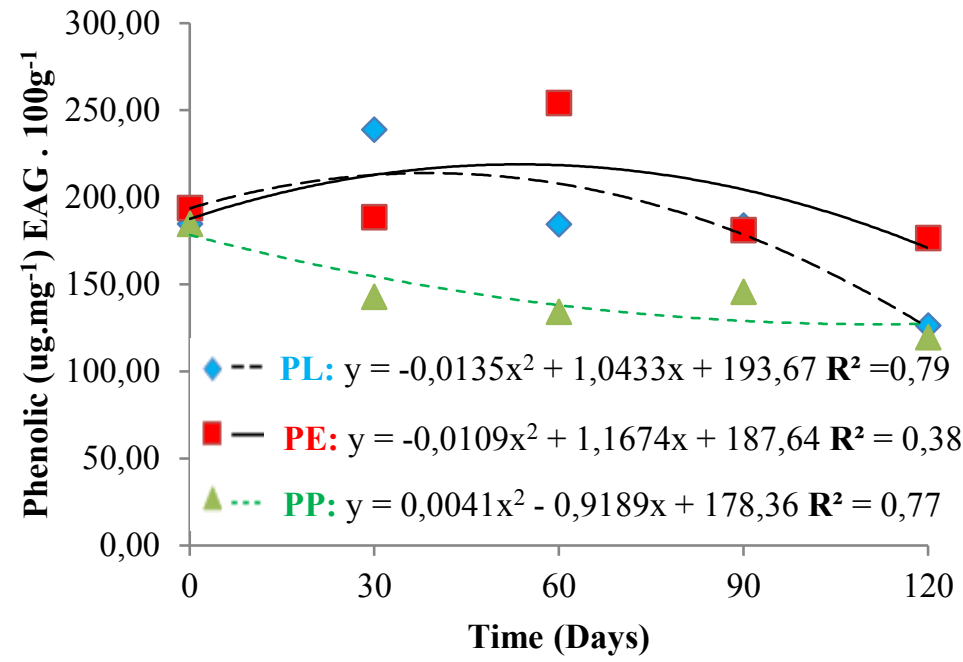

Figure 5. Phenolic compounds content of raisins stored for 120 days in different packages. PL: Laminated Polyethylene; PE: polystyrene with lid; PP: Transparent polypropylene.

Vilas Boas et al. (2016), evaluating the phenolic content in blends of grape juices produced in the southwest of Minas Gerais state, observed average values of $257.12 \mathrm{mg} .100 \mathrm{~mL}^{-1}$ for a Niagara $\times$ BRS Cora $\times$ BRS Violet blend during a storage time of 120 days, also observed that, during that time, these compounds were reduced. When evaluating the phenolic content of other grape product, Rigotti et al. (2016), obtained an amount of $176.32 \pm 2.82 \mathrm{mg} \mathrm{EAG} 100 \mathrm{~mL}^{-1}$ in wines produced from the Isabel variety. Lins and Sartoni (2014), emphasize that these substances are important due to the antioxidant activity, promoting health and that the consumption of grapes and wines is associated with a low incidence of cardiovascular diseases.

The association between antioxidants and phenolic compounds with health justify the maintenance of these compounds stability during processing and storage. The type of packaging must be taken into consideration aiming the maintenance substances and bioactive compounds (CAMPOS et al., 2008). Antioxidant compounds can be degraded by light, oxygen and heat, for example (CAMPOS et al., 2008). The type of packaging selected should then avoid the degradation of these bioactive compounds.

Fruits stored in different packages were not different regarding their anthocyanin contents, presenting an average content of $40.7 \mathrm{mg} \cdot \mathrm{L}^{-1}$ during storage 
(Figure 6). These substances may vary according to the grape's cultural traits, climate condition and variety. In a study by Machado, Souza and Novaes (2015), values of $378.95 \mathrm{mg} .100 \mathrm{~g}^{-1}$ were observed for dehydrated Isabel grapes. The permeability in packages may influence the anthocyanin content, since the oxygen can degrade anthocyanin through oxidation, independently of the light presence (CARNEIRO et al., 2016).

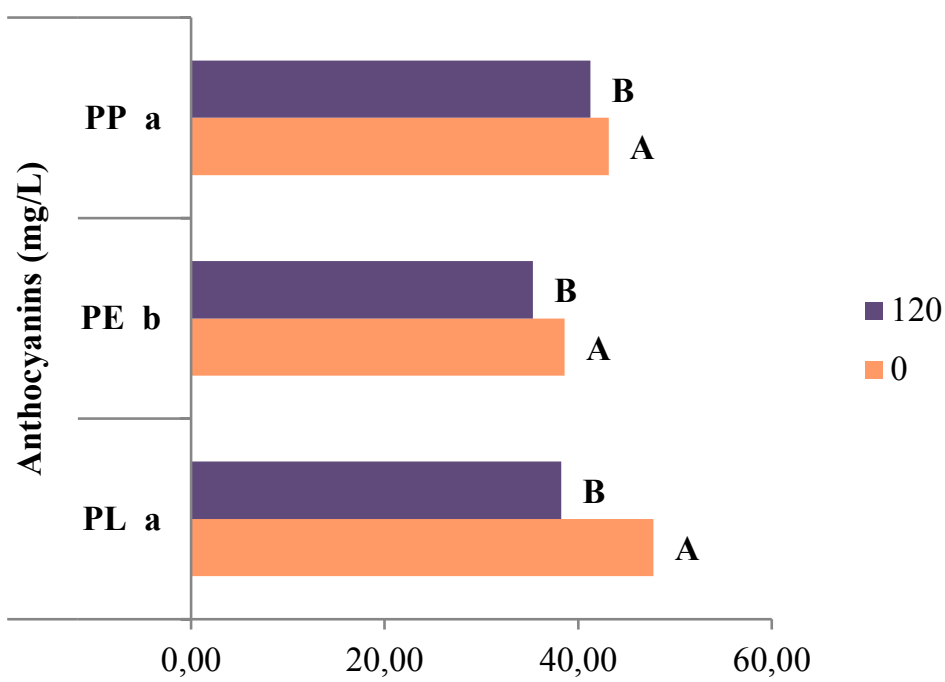

Figure 6. Anthocyanin of raisins stored for 120 days in different packages. PL: Laminated Polyethylene; PE: polystyrene with lid; PP: Transparent polypropylene. Equivalent capital letters for the same time of evaluation: means do not differ according to the Tukey's test

a ( $p>0.05)$ probability. 0 days (0) and 120 days (120). Same lowercase letters: de packages did not influenced the anthocyanin content according to the Tukey's test at $5 \%$ of probability.

The pigments, in grapes, are responsible for the color characterization and the development and integrity of these pigments are mainly influenced by light and temperature (GUINÉ et al., 2010). Anthocyanin are an example of sensitive compounds to this factor and can be degraded by photochemical action. Shimamoto and Rossi (2010), observed the effect of light on the degradation of Jussara (Euterpe edulis) anthocyanin extract and demonstrated that the interaction between UV radiation and light in anthocyanin-containing extracts can modify its stability and promote the formation of products from oxidative degradation, of a brownish color.

Chemically, these substances are phenolic compounds that become important in the human diet preventing cardiovascular diseases and cancer, due to their potential to scavenging free radicals, in addition to reducing cholesterol and triglyceride levels (SANTOS et al., 2014). Currently, they can be obtained from the consumption of fruits such as grapes, mulberry, cherry, apple, among others or from nutritionally enriched foods (SANTOS et al., 2014). A study by Bonfietti (2017), demonstrated the increase in nutritional value through the addition of these natural pigments, from açaí powder to cookies. 
According to the FAO (2014), the largest losses of food production are attributed to inadequate handling, distribution, storage and consumption behavior. Wastes can often be reduced by the use of appropriate packaging, whose essential function is to conserve and protect food, keeping it free of significant changes in its sensory and constitutional aspects, as well as preserving its useful life by having paper barriers against agents responsible for their damage (DONATTI, 2011).

During storage, dried fruits can be exposed to different conditions, such as different temperatures, humidity, luminosity, oxygen, and then initiate physicalchemical changes (UDOMKUN et al., 2016).

From the multivariate statistics, Principal Components Analysis (PCA), which explained $59.25 \%$ of the results, it was possible to correlate the different variables and treatments studied. In Figure 7 it is possible to clearly visualize that the storage time had a greater influence on the results in detriment of the packages. It can be concluded by verifying groups of the same storage time in the different quadrants, regardless of the packaging used. The vectors that represent the result of antioxidant activity and luminosity are close, indicating a positive correlation between these variables that can be related through antioxidant pigments that provide the coloring of the fruits. On the other hand, $\mathrm{pH}$ and firmness presented a negative correlation, indicating that there was no influence of one on the other, the opposition of quadrants between $\mathrm{pH}$ and the results after the 30 days emphasize that this variable is in low values when compared to the other treatments. It is also noted that some variables ( $L^{*}$, antioxidant activity, acidity and $b^{*}$ ) were more expressive at 60 days of storage, regardless of the packaging.

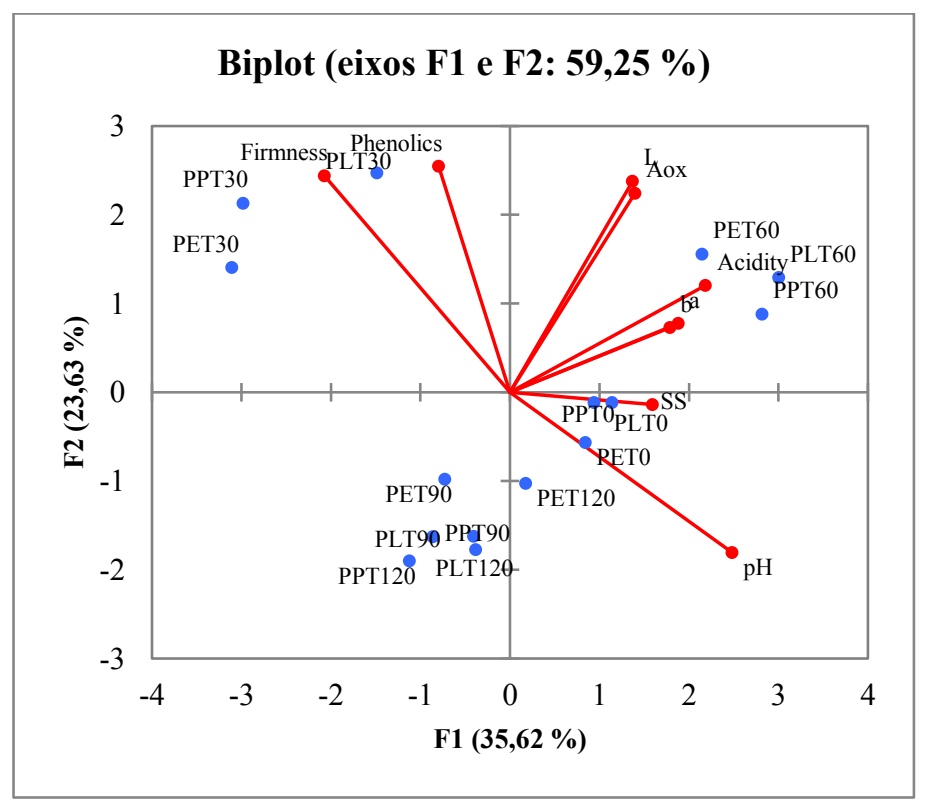

Figure 7. Principal Components Analysis (PCA) of raisins stored for 120 days in different packages. PL: Packaging Laminated Polyethylene; PE: polystyrene with lid; PP: Transparent Polypropylene. and firmness, factors desirable by consumers, regardless of the packaging in which 
they were stored. Fruits stored for 60 days presented more acidity and higher antioxidant activity. Higher contents of soluble solids contents were observed in products in the first time of evaluation.

The F1 and F2 principal components were able to explain $59.25 \%$ of the results. The $\mathrm{F} 1$ presents positive associations with $\mathrm{pH}$, acidity and for the raisins stored for 60 days. The $\mathrm{F} 2$ principal component presented a positive association with firmness, phenolic compounds and for the raisins stores at 30 days, regardless the package used. In cases that the sum of the principal components do not achieve $80 \%$ to explain the variables, the analysis loose reliability, being advised the use of the other principal components (F3, F4, etc.). Vectors with larger sizes indicate greater importance of the component in the explanation of the total variation within the data set. This fact means that the eigenvalue explains the

importance of the component on the total presented data. In the case of the presented PCA (Figure 7), the vectors related to the color parameters a* and $b^{*}$ and to the soluble solids content presented smaller sizes, with less importance of the variation within the presented data.

The hypothesis tested considers that different packages could influence the maintenance of compounds of interest of raisins. It was expected that the laminated polyethylene ( $\mathrm{PL}$ ) package would better retain these substances due to the characteristics of light protection, which would avoid, for example, significant color changes, mainly provided by the aluminum material. However, for most of the studied variables, no significant effect of the packages was observed in the condition in which the experiment was performed. For example, phenolic compounds are a group of antioxidants, and these substances are unstable in the presence of oxygen (CAMPOS et al., 2008). The oxygen could influence the significance and interaction between storage time and packaging, since when the PE package was evaluated, a lid was used, restricting the oxygen available for the raisins.

\section{CONCLUSIONS}

The studied packaging materials did not provide significant changes in the evaluated quality parameters of 'BRS Vitória' raisins. Thus, the most suitable packaging for producers becomes the one with the lowest cost, the transparent polypropylene (PP). During storage a reduction in the antioxidant content was observed, however, the raisins presented high levels of these substances during the entire storage time. According to the multivariate analysis, the storage time was the main influencing factor of the variables studied, regardless of the packaging used. 


\title{
Uso de embalagens na manutenção da qualidade de uvas passa BRS Vitória
}

\author{
RESUMO
}

A partir do cultivo da uva é possível à obtenção de produtos processados, como vinhos, sucos e uvas passa. A fruta desidratada é bastante consumida nacionalmente devido aos benefícios que proporciona, sendo um produto com teores de compostos fenólicos e atividade antioxidante. A variedade 'BRS Vitória' foi recentemente lançada no Brasil, tendo um alto potencial para produção de uva passa, porém ainda não existem estudos conclusivos sobre o uso de embalagens para a manutenção da qualidade de uvas passas obtidas da variedade 'BRS Vitória'. O objetivo do presente estudo foi avaliar o efeito de três embalagens na manutenção de parâmetros de qualidade da uva passa 'BRS Vitória' durante sua vida útil por um período de 120 dias. Uvas passa, obtidas após secagem em estufa com circulação forçada de ar a $60^{\circ} \mathrm{C}$, durante cerca de 72 horas, foram embaladas em polietileno (PL) metalizado selado, polipropileno transparente (PP) e poliestireno (PE) com tampa. As amostras de uva passa foram avaliadas aos 0,30 , 60,90 e 120 dias de armazenamento a $25^{\circ} \mathrm{C}$ quanto à acidez titulável, pH, cor, sólidos solúveis, firmeza, atividade antioxidante, fenólicos totais, antocianinas. Os resultados obtidos foram submetidos à análise de variância (ANOVA). Além disso, foi realizada uma análise estatística multivariada. A partir dos resultados, observou-se que as embalagens não proporcionaram mudanças significativas nos parâmetros de qualidade avaliados em uvas passa 'BRS Vitória', indicando que a embalagem adequada se torna a que possui menor custo, a de polipropileno transparente. A atividade antioxidante foi influenciada apenas pelo tempo de vida de prateleira, permanecendo ao final com níveis consideráveis de conteúdo antioxidante. Além disso, o tempo de armazenamento também influenciou a firmeza e a cor das passas. Constatou-se que somente para os fenólicos houve interação significativa entre tempo de armazenamento e embalagem. De acordo com a análise multivariada, o tempo de armazenamento foi o principal fator de influência das variáveis estudadas, independentemente da embalagem utilizada.

PALAVRAS-CHAVE: Frutas desidratadas; armazenamento; compostos fenólicos; atividade antioxidante. 


\section{REFERENCES}

AOAC - Association of Analytical Chemists. Official methods of the Association of the Agricultural Chemists. 19th edition, AOAC international. Whashington, 2012.

BONFIETTI, N. F. Desenvolvimento e análise sensorial de cookies de quinoa enriquecidos com pigmentos naturais. Revista Saúde UniToledo, v. 01, n. 01, p. 31-46, 2017.

BRASIL. Leis, Decretos, etc. Instrução normativa №1 de 7 de janeiro de 2000. Regulamento técnico geral para a fixação dos padrões de identidade e qualidade para polpa de fruta, 2000.

BREKSA, A. P.; TAKEOKA, G. R.; HIDALGO, M. B.; VILCHES, A.; VASSE, J.; RAMMING, D. W. Antioxidant activity and phenolic content of 16 raisin grape (Vitis vinifera L.) cultivars and selections. Food Chemistry, v. 121, Issue 3, p. 740745, 2010. https://doi.org/10.1016/j.foodchem.2010.01.029.

BRILHANTE, S. E. T.; NETO, F. B. O.; ALCÂNTARA, L. A.; BERTINI, L. M. Determinação do teor de antocianinas e sua influência na variação da coloração dos extratos de flores do oeste potiguar. IX Congresso de Iniciação Científica do IFRN, Currais Novos - RN: Anais, p. 636 - 644, 2013.

CAMPOS, F. M.; MARTINO, H. S. D.; SABARENSE, C. M.; PINHEIRO-SANT'ANA, H. $M$. Estabilidade de compostos antioxidantes em hortaliças processadas: uma revisão. Alimentos e Nutrição, v.19, n.4, p. 481-490, 2008.

CARNEIRO, L. M.; PIRES, C. R. F.; LIMA, J. P.; PEREIRA, P. A. P.; LIMA, L. C. O. Avaliação da estabilidade de geleias de amora-preta acondicionadas em diferentes embalagens. Journal of Bioenergy and Food Science. v.3, n.2, p.89102, 2016. http://dx.doi.org/10.18067/jbfs.v3i2.99.

CARRANZA-CONCHA, J.; BENLLOCH, M.; CAMACHO, M.M.; MARTÍNEZNAVARRETE, N. Effects of drying and pretreatment on the nutritional and functional quality of raisins. Food and Bioproducts Processing, v. 90, n. 2, p. 243248, 2012. https://doi.org/10.1016/j.fbp.2011.04.002.

CONDE, A.; SOARES, F.; BREIA, R.; GERÓS, H. Postharvest dehydration induces variable changes in the primary metabolism of grape berries. Food Research International, v. 105, p. 261-270, 2018.

https://doi.org/10.1016/j.foodres.2017.11.052 
CORNEJO, F. E. P.; NOGUEIRA, R. I.; WILBERG, V. C. Secagem como Método de Conservação de Frutas. Ministerio da agricultura, Pecuária e abastecimento. Documentos 54. Embrapa, ISSN 0103-6068 54, Rio de Janeiro, RJ, 2003.

COSTA, J. D. S.; NETO, A. F.; NUNES, S. M.; RYBKA, A. C. P.; BIASOTO, A. C. T.; FREITAS, S. T. Caracterização Física e Fisico-química de Uva Itália Desidratada. Revista Iberoamericana de Tecnología Postcosecha, v. 16, n. 2, p. 273-280, 2015.

DU, B.; HE, B. J.; SHI, P. B.; LI, F. Y.; LI, J.; ZHU, F. M. Phenolic content and antioxidant activity of wine grapes and table grapes. Journal of Medicinal Plants Research, v. 6, n. 17, pp. 3381-3387, 2012. 10.5897/JMPR12.238.

FAO. Appropriate food packaging solutions for developing countries. Rome, 2014.

FELDBERG, N. P.; MOTA, R. V.; SIMÕES, W. L.; REGINA, M. A. Viabilidade da Utilização de Descartes de Produção de Uvas sem Sementes para elaboração de Passas. Revista Brasileira de Fruticultura, v. 30, n. 3, p. 846-849, Setembro, 2008. http://dx.doi.org/10.1590/\$0100-29452008000300050.

FREITAS, A. A.; FRANCELIN, M. F.; HIRATA, G. F.; CLEMENTE, E.; SCHMIDT, F. L. Atividades das enzimas peroxidase (POD) e polifenoloxidase (PPO) nas uvas das cultivares benitaka e rubi e em seus sucos e geleias. Ciência e Tecnologia de Alimentos, v. 28, n. 1, p. 172-177, 2008.

FREITAS, D. G. C.; MACHADO, J. A.; MATTOS, C. T. G. B.; NOGUEIRA, R. I.; CORNEJO, F. E. P.; SOUZA, R. T.; MAIA, J. D. G.; RITSCHEL, P. S. Aceitação de Uvas Passas Brasileiras e suas Características Sensoriais Segundo a Percepção do Consumidor. Circular Técnica 192. Embrapa, ISSN 0103 5231, Rio de Janeiro, RJ, 2013.

GOUVEIA, A. M. S.; CORREIA, C. V.; TAVARES, A. E.; EVANGELISTA, R. M.; CARDOSO, A. I. I. Qualidade de Raízes de Batata-Doce em Função da Adubação Nitrogenada e Conservação. Revista Raízes e Amidos Tropicais, v. 10, n. 1, p. 5764, 2014. http://dx.doi.org/10.17766/1808-981X.2014v10n1p57-64.

GUINÉ, R. P.; PALIYATH, G.; PESSOA, F. L.; LE QUÉRÉ, J. L.; SIDHU, J. S.; SINHA, N. Handbook of fruit and vegetable flavors. Y. H. Hui, F. Chen, \& L. M. Nollet (Eds.). John Wiley and Sons. New Jersey, 1118 p., 2010.

HOFFMANN, F. L. Fatores limitantes à proliferação de microrganismos em 
JAVED, H. U.; WANG, D.; SHI, Y.; WU, G. F.; XIE, H.; PAN, Y. Q.; DUAN, C. Q. Changes of free-form volatile compounds in pre-treated raisins with different packaging materials during storage. Food Research International, v. 107, p. 649659, 2018. doi:10.1016/j.foodres.2018.03.019.

LINS, A. R.; SARTONI, G. V. Qualidade Fenólica e Atividade Antioxidante de Vinhos Tintos Produzidos no Estado do Paraná. Revista Brasileira de Produtos Agroindustriais, v.16, n.1, p.69-76, 2014.

MACHADO, A. V.; SOUZA, J. A.; NOVAES, R. S. Estudo cinético da secagem da uva Isabel para produção de uva passa. Revista Verde, v. 10, n.1, p. 47-51, 2015. http://dx.doi.org/10.18378/rvads.v10i1.3324.

MAIA, J. D. G.; RITSCHEL, P.; CAMARGO, U. A.; SOUZA, R. T.; FAJARDO, T. V.; NAVES, R. L.; GIRARDI, C. L. 'BRS Vitória' Nova cultivar de uva de mesa sem sementes com sabor especial e tolerante ao míldio. Comunicado Técnico 126. Embrapa, ISSN 1516-8093, Bento Gonçalves, RS, 2012.

MASCARENHAS, R. J.; SILVA, S. M.; LOPES, J. D.; LIMA, M. A. C. Avaliação Sensorial de Uvas de Mesa Produzidas no Vale do São Francisco e Comercializadas em João Pessoa-PB. Revista Brasileira de Fruticultura, v. 32, n. 4, p. 993-1000, 2010.

MELLO, L. M. R. Desempenho da vitivinicultura brasileira em 2015. Embrapa Uva e Vinho, 2016.

NOBRE, J. A. S.; LIMA, D. M. Tecnologia do Processamento de Alimentos. Projeto Formare. Grupo Ibmec Educacional, São Paulo, 448p., 2011.

OECD; FAO. Agricultural Outlook 2015-2024. OECD I Library, 2015.

RAMOS, A. M.; QUINTEIRO, A. C. F.; FARAONI, A. S.; SOARES, N. F. F.; PEREIRA, J. A. M. Efeito do Tipo de Embalagem e do Tempo de Armazenamento nas Qualidades Físico-Química e Microbiológica de Abacaxi Desidratado. Alimentos e Nutrição, v.19, n.3, p. 259-269, 2008.

RIGOTTI, M.; BRANCO, C. S.; ANDRADE, L. B.; HORVARTH, J. D. C.; SALVADOR, MIRIAN. Atividade antioxidante e teor de polifenóis totais de vinhos de mesa da Serra Gaúcha. Revista Uniplac, v.1, n.1, p. 48-60, 2016.

RIZZON, L. A.; SGANZERLA, V. M. A. Ácidos tartárico e málico no mosto de uva em Bento Gonçalves-RS. Ciência Rural, v. 37, n. 3, p. 911-914, 2007. 
RYBKA, A. C. P.; FREITAS, S. T.; NETTO, A. F.; BIASOTO, A. C. T. Central composite rotatable design approach to optimize 'Italia' raisin drying conditions.

Comunicata Scientiae, v. 6, n. 4, p. 454-462, 2015. 10.14295/CS.v6i4.993.

ROCHA, D. S.; REED, E. Pigmentos Naturais em Alimentos e sua Importância para a Saúde. Estudos Vida e Saúde, v. 41, n. 1, p. 76-85, jan./mar, 2014. http://dx.doi.org/10.18224/est.v41i1.3366.

ROTILI, M. C. C.; COUTRO, S.; CELANT, V. M.; VORPAGEL, J. A.; BARP, F. K.; SALIBE, A. B.; BRAGA, G. C. Composição, atividade antioxidante e qualidade do maracujá amarelo durante armazenamento. Semina: Ciências Agrárias, v. 34, n. 1, p. 227 240, 2013. 10.5433/1679-0359.2013v34n1p227.

RUFINO, M. S. M.; ALVES, R. E.; BRITO, E. S.; MORAIS, S. M.; SAMPAIO, C. G.; JIMENEZ, J. P.; CALIXTO, F. D. S. Determinação da atividade antioxidante total em frutas pela captura do radical livre DPPH. Comunicado Técnico Embrapa, 127: 14, 2007.

SANTOS, A. C. A.; MARQUES, M. M. P.; SOARES, A. K. O.; FARIAS, L. M.; FERREIRA, A. K. A.; CARVALHO, M. L. Potencial antioxidante de antocianinas em fontes alimentares: revisão sistemática. Revista Interdisciplinar. v. 7, n. 3, p. 149-156, 2014.http://revistainterdisciplinar.uninovafapi.edu.br/index.php/revinter/article/ view/467.

SANTOS, E. H. B.; AZEVÊDO, L. C.; BATISTA, F. P. R.; MATOS, L. P.; LIMA, M. S. Caracterização química e sensorial de uvas desidratadas, produzidas no Vale do São Francisco para infusão. Revista Semiárido De Visu, v.1, n.2, p.134-147, 2011.

SANTOS, M. P.; OLIVEIRA, N. R. F. Ação das vitaminas antioxidantes na prevenção do envelhecimento cutâneo. Disciplinarum Scientia. Série: Ciências da Saúde, v. 15, n. 1, p. 75-89, 2013.

SCHIOZER, A. L.; BARATA, L. E. S. Estabilidade de Corantes e Pigmentos de Origem Vegetal. Revista Fitos, v. 3, n. 02, p.6-24, 2007.

SÉRIO, S.; RIVERO-PÉREZ, M. D.; CORREIA, A. C.; JORDÃO, A. M.; GONZÁLEZ-SAN JOSÉ, M. L. Analysis of commercial grape raisins: phenolic content, antioxidant capacity and radical scavenger activity. Ciência e Técnica Vitivinícola, v. 29, n. 1, p. 1-8, 2014. http://dx.doi.org/10.1051/ctv/20142901001.

SHIMAMOTO, G. G.; ROSSI, A. V. Estudo do efeito da luz na degradação de 
05/2010, 33a Reunião Anual da Sociedade Brasileira de Química - SBQ, v. 1, pp.61-61, Águas de Lindóia, SP, Brasil, 2010.

SILVA, G. S.; SANTOS, S. P. S.; BARBOSA, N. F. P.; SANTOS, R. G.; BERY, C. S.; SILVA, G. F. Secagem e Caracterização Físico-Química da Uva Crimson. XXXVII

Congresso Brasileiro de Sistemas Particulados, v. 2, n. 1, Anais: p. 2071 - 2076, São Carlos - SP, 2015. 10.5151/ENEMP2015-TC-742.

SINGLETON, V. L.; ORTHOFER, R.; LAMUELA-RAVENTOS, R. M. Analysis of total phenols and other oxidation substrates and antioxidants by means of FolinCiocalteu reagent. Method Enzymol. 1999, 299, 152-178.

SOUZA, R. T.; CORNEJO, F. E. P.; NOGUEIRA, R. I.; FREITAS, D. G. C.; PROTAS, J. F. S.; MAIA, J. D. G.; MATTOS, C. T. G. B.; LEAL JUNIOR, W. F.; RITSCHEL, P. S. Uvaspassas Brasileiras: Matéria-prima e Processamento. Circular Técnica 115. Embrapa, ISSN 1516-5914, Bento Gonçalves, RS, 2015.

UDOMKUN, P.; NAGLE, M.; ARGYROPOULOS, D.; MAHAYOTHEE, B.; LATIF, S.; MULLER, J. Compositional and functional dynamics of dried papaya as affected by storage time and packaging material. Food Chemistry, v. 196, p. 712-719, 2016. http://doi.org/10.1016/j.foodchem.2015.09.103.

VILAS BOAS, A. C.; HENRIQUE, P. C.; LIMA, L. C. O.; NETO, A. C.; NASSUR, R. C. M. R.; LIMA, R. A. Z. Atividade antioxidante e fenólicos totais em blends de sucos de uvas americanas produzidas no sudoeste de Minas Gerais. Boletim do CEPPA, v. 34, n. 1, p. 15-26, 2016. http://dx.doi.org/10.5380/cep.v34i1.48969.

ZHANG, H.; TSAO, R. Dietary polyphenols, oxidative stress and antioxidant and anti-inflammatory effects. Current Opinion in Food Science. v. 8, p. 33-42, 2016. http://dx.doi.org/10.1016/j.cofs.2016.02.002.

Recebido: 13 nov. 2017.

Aprovado: 30 ago. 2018.

DOI: $10.3895 /$ rebrapa.v9n3.7326

Como citar:

CALDEIRA, V. F. et al. Packages influencing BRS Vitória raisins quality maintenance. Brazilian Journal of Food Research, Campo Mourão, v. 9, n. 3, p. 138-156, jul./set. 2018. Disponível em:

https://periodicos.utfpr.edu.br/rebrapa

Correspondência:

Rita de Cássia Mirela Resende Nassur

Universidade do Estado da Bahia, Departamento de Tecnologia e Ciências Sociais, DTCS, Campus III, Rua Edgard Chastinet, São Geraldo, CEP 48905680, Juazeiro, Bahia, Brasil

Direito autoral: Este artigo está licenciado sob os termos da Licença Creative Commons-Atribuição 4.0 Internacional. 